\title{
Clinical application of scaffolds for cartilage tissue engineering
}

\author{
Junji Iwasa $\cdot$ Lars Engebretsen $\cdot$ Yosuke Shima • \\ Mitsuo Ochi
}

Received: 17 March 2008/Accepted: 24 October 2008/Published online: 20 November 2008

(c) The Author(s) 2008. This article is published with open access at Springerlink.com

\begin{abstract}
The purpose of this paper is to review the basic science and clinical literature on scaffolds clinically available for the treatment of articular cartilage injuries. The use of tissue-engineered grafts based on scaffolds seems to be as effective as conventional ACI clinically. However, there is limited evidence that scaffold techniques result in homogeneous distribution of cells. Similarly, few studies exist on the maintenance of the chondrocyte phenotype in scaffolds. Both of which would be potential advantages over the first generation ACI. The mean clinical score in all of the clinical literature on scaffold techniques significantly improved compared with preoperative values. More than $80 \%$ of patients had an excellent or good outcome. None of the short- or mid-term clinical and histological results of these tissue-engineering techniques with scaffolds were reported to be better than conventional ACI. However, some studies suggest that these methods may reduce surgical time, morbidity, and risks of periosteal hypertrophy and post-operative adhesions. Based on the
\end{abstract}

J. Iwasa $(\varangle) \cdot$ L. Engebretsen · Y. Shima

Oslo Sports Trauma Research Center, Norwegian School

of Sport Sciences, P.O. Box 4014, Ullevaal Stadion,

0806 Oslo, Norway

e-mail: junjiiwasa@yahoo.co.jp

L. Engebretsen $(\square)$

Orthopaedic Center, Ullevaal University Hospital, 0407 Oslo, Norway

e-mail: lars.engebretsen@medisin.uio.no

M. Ochi

Department of Orthopaedic Surgery, Graduate School of Biomedical Science, Hiroshima University,

1-2-3 Kasumi, Minami-ku, Hiroshima 734-8551, Japan

L. Engebretsen

Faculty of Medicine, University of Oslo, 0407 Oslo, Norway available literature, we were not able to rank the scaffolds available for clinical use. Firm recommendations on which cartilage repair procedure is to be preferred is currently not known on the basis of these studies. Randomized clinical trials and longer follow-up periods are needed for more widespread information regarding the clinical effectiveness of scaffold-based, tissue-engineered cartilage repair.

Keywords Articular cartilage · Tissue engineering · Scaffold · Autologous chondrocyte implantation . Matrix-induced autologous chondrocyte implantation

\section{Introduction}

The repair of articular cartilage defects in the knee of young or active individuals remains a problem in orthopedic practice. These defects have limited ability to heal and may progress to osteoarthritis. They may be symptomatic and cause pain, swelling and catching. In a study of 993 consecutive arthroscopies done in patients with knee pain [2], articular cartilage changes were noted in $66 \%$ of the knees and isolated, localized cartilage lesions in about $20 \%$ of the cases. Full thickness cartilage lesions were found in $11 \%$ of the knees and $6 \%$ were larger than $2 \mathrm{~cm}^{2}$.

Several different surgical procedures have been applied to treat cartilage injuries, but no method has been judged superior. At present, more than 5,000 Medline citations are available on surgical cartilage treatment. Microfracture technique, as a low cost and minimally invasive procedure, is currently being used as the first choice in patients with previously untreated cartilage defects. However, histological analysis of repair tissue after these operations shows mainly fibrocartilage. Advantages of mosaicplasty or osteochondral autologous grafts are that defects can be 
filled immediately with mature, hyaline articular cartilage and that both chondral and osteochondral defects can be treated in the same way. However, donor site morbidity is a concern and the long-term results of the harvesting procedure are not known. Of the numerous techniques available today, no method has yet been able to consistently reproduce normal hyaline cartilage. One such method is autologous chondrocyte implantation (ACI), described by Brittberg et al. in 1994 [11]. The introduction of ACI into clinical practice has enabled the application of tissue-engineering techniques with a cell-based therapy that allows regeneration of damaged cartilage tissue. Although the short- or middle-term clinical results of ACI were reported as good [74, 87], this procedure has potential disadvantages, such as the risk of leakage of transplanted chondrocytes from the cartilage defects, an uneven distribution of chondrocytes in the transplanted site due to gravity [101], periosteal hypertrophy [42, 104], complexity of the surgical procedure [67], and not the least the reacquisition of phenotypes of dedifferentiated chondrocytes in a monolayer culture $[8,59]$.

In order to overcome some of these hurdles, researchers have attempted to reconstruct cartilage in the laboratory using tissue engineering, a technique by which a living tissue can be reconstructed by associating the cells with biomaterials that provide a scaffold on which they can proliferate three-dimensionally, under physiological conditions. The scaffold technique may have the technical and theoretical advantages such as less invasive technique because of no need to harvest periosteum, as well as homogeneous distribution of chondrocytes and the maintenance of the phenotype. Carriers have been marketed and various tissue-engineering techniques, widely used nowadays, have been developed using chondrocytes seeded on biological matrices such as collagen membranes [22] or hyaluronic acid [67]. Despite the diffusion of these methods, the ideal matrix material has not been identified, and there are still some areas that would need better clarification. It has not verified that the technical and theoretical advantages of scaffold techniques have led to the better clinical and histological results compared with conventional ACI. Therefore, a review of current developments in scaffolds for cartilage tissue engineering in clinical use and future perspectives are necessary.

The aim of this review is to assess the literature of clinically available scaffolds used for the treatment of articular cartilage injuries in order to know the current status of scaffolds for cartilage tissue engineering. Although tissue engineering consists of three major parts; transplanted cells, scaffold for cell proliferation, and growth factors, we focus on the literature on scaffolds in clinical use. In addition, this article details the evidence from studies on the clinical outcome of tissue-engineered cartilage repair. The main questions to be answered are: do advanced cartilage tissue-engineering grafts ensure even distribution of a high number of vital chondrocytes, mediate initial biomechanical stability, promote chondrocyte differentiation and the formation of cartilage matrix, thereby yielding better clinical outcomes with decreased complications, compared with conventional $\mathrm{ACI}$ ?

\section{Current cartilage repair strategies and tissue engineering}

Historical unsatisfactory results of cartilage injury reflect the poor healing capacity of cartilage arising from its isolation from systemic regulation, and its lack of vessels and nerve supply [66]. None of the normal inflammatory and reparative processes is available for its repair. Furthermore, chondrocytes which are surrounded by an extracellular matrix cannot migrate to the site of injury from an intact healthy site, unlike most tissues [16]. Injuries which reach the subchondral bone may induce a systemic reaction and generate reparative tissue. The new tissue consists predominantly of type I collagen, resulting in the formation of fibrocartilage. Type I collagen does not have the biomechanical properties of articular cartilage. Accordingly, it cannot function as normal hyaline cartilage and eventually degenerates [32].

ACI was first described in 1994 [11]. The procedure involves the patient having to undergo harvesting through an arthroscopic procedure, followed 2-8 weeks later an arthrotomy, where the cells are injected under a cover of periosteum. The original ACI technique involved the injection of a suspension of cultured chondrocytes into a debrided chondral defect beneath a periosteal cover. Clinical results from femoral defects have ranged from 60 to $90 \%$ excellent and good between 1 to 11 years after surgery $[7,11,14,26,37,44,46,47,51,61,62,73,74,76$, 77, 87-89].

As mentioned, the ACI procedure has several disadvantages. Especially, hypertrophy of tissue seemed to be the major cause for re-operations after ACI [37, 42, 78, 104]. Using collagen membranes instead of periosteum could possibly reduce the risk for re-operations. Several studies showed a lower incidence of graft hypertrophy after ACI with a type I/III collagen membrane $[7,10,37,42,63$, 104]. As further technological advances, researchers have initiated the use of carrier i.e., a scaffold or matrix upon which the cells are grown. The use of three-dimensional scaffolds has enabled maintenance of a chondrocyte differentiated phenotype. A further advantage of this method of cell delivery is that the scaffold may act as a barrier 
to the invasion of the graft by fibroblasts, which may otherwise induce fibrous repair [29]. In addition, most of the articular cartilage engineering techniques with scaffolds can be done without a periosteal or membrane coverage and in many cases using arthroscopic techniques. Consequently, the procedures may be performed faster and with a less extensive exposure.

\section{Scaffolds available for clinical application}

The scaffold must be biocompatible, structurally and mechanically stable, must support the loading of an appropriate cell source to allow successful infiltration and attachment with appropriate bioactive molecules in order to promote cellular differentiation and maturation, and must be biodegradable, giving temporary support. Several natural biomaterials, such as collagen [20, 98, 116], hyaluronan [39], fibrin glue [48, 50], alginate [3, 41, 43, 72, 96, 106], agarose [8, 92, 105], or chitosan [99], as well as synthetic biomaterials such as polylactic acid [23] have been developed for the restoration of damaged cartilage. However, the clinical use of these materials is currently limited, mainly due to the risk of disease transmission and immunoreaction.

The inclusion criteria for studies on scaffolds available for clinical application were use of in vitro or in vivo or clinical studies on scaffolds with clinical trial. Several studies on scaffolds such as alginate, agarose and chitosan were excluded because of no clinical experience. Ultimately studies on collagen, hyaluronan-based polymer, fibrin, and synthetic copolymer scaffold were included in this review based on the inclusion criteria. Collagen and hyaluronan-based matrices are among the most popular natural scaffolds in clinical use nowadays, as they offer a substrate that would normally be found in the structure of native articular cartilage. Our literature searches are based on MEDLINE In-process and other Non-Indexed Citations, EMBASE, and CINAHL using Ovid searches of articles published between 1 January 1966, and 1 March 2008. Therefore, we acknowledge that the most important limitation of this study is the limitation of the already existing studies.

\section{A bilayer collagen type I-III membrane}

Collagen is one of matrix proteins occurring as a major component of connective tissues, giving it strength and stability. Collagen scaffolds have been used extensively for cartilage regeneration for decades $[19,20,38,98,116$, 117]. Collagen can be fabricated as a membrane, gel, sponge or foam and is subject to enzymatic degradation.
Matrix-induced ACI (MACI ${ }^{\circledR}$; Verigen, Leverkusen, Germany) can be considered as an evolution of conventional ACI. The MACI technique is a tissue-engineering technique in which the principle of autologous cell culture is preserved: a bilayer collagen I-III scaffold is used to improve the structural and biological properties of the graft. MACI uses processed cells that are harvested and isolated from the patient and expanded in vitro. Once grown, the chondrocytes are seeded between layers of a bilaminate collagen in the operating room prior to implantation. The MACI membrane can be secured directly to the base of a prepared chondral defect by fibrin glue and without a cover. The surgical procedure is quite simple, requiring short operating time. The MACI technique was introduced in 1999 (Fig. 1) [22].

Other MACI membranes such as Maix ${ }^{\circledR}$ (Matricel, Hezoenrath, Germany) or Chondro-Gide ${ }^{\circledR}$ (Geistlich Biomaterials, Wolhusen, Switzerland) consist of a porcine type I/type III collagen bilayer seeded with chondrocytes. These membranes are degraded by enzymatic digestion and have two different surfaces: the external has good mechanical strength and serves as a barrier, whereas the inner surface is porous and stimulates the cells to produce cartilage-specific matrix molecules [33]. This membrane has been used extensively in dental and maxillofacial surgery since 1980 [24]. A number of in vitro and in vivo studies have demonstrated that this multilayer threedimensional scaffold is an excellent medium for cell attachment, maintaining the phenotype of chondrocytes

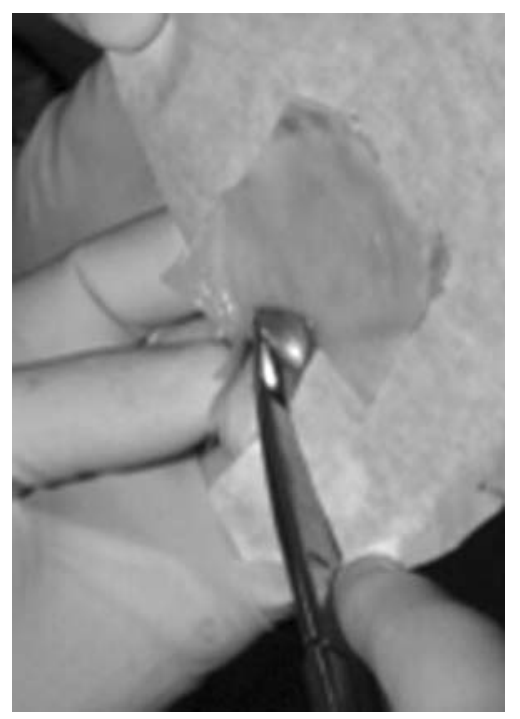

Fig. 1 The matrix-induced autologous chondrocyte implantation procedure. Reprinted by permission from Cherubino et al. [22] "Autologous chondrocyte implantation using a bilayer collagen membrane: a preliminary report. J Orthop Surg (Hong Kong) 11:10-15" 
overtime as well as delivering a dense superficial layer to keep the cells in the defect and limit the migration of inflammatory proteins into the repair site. [27, 29, 33, 34, 55, 79-81, 118]. Furthermore, in a recent sheep study, a multidefect cartilage repair model demonstrated that collagen matrix seeded with autologous chondrocytes produced better quantitative and qualitative results compared with microfracture [25].

Gigante et al. [35] analyzed the distribution, viability and phenotype expression of human chondrocytes seeded on a collagen membrane at the time of the implantation. The residual part of each membrane from 12 patients who underwent MACI was tested by colorimetric assay and histochemical and ultrastructural analyses were carried out. In all of the samples a large number of viable cells, homogenously distributed, were detected. The cells expressed the markers of the differentiated hyaline-producing chondrocytes [35].

\section{Collagen type I gel}

Ochi et al. [83] reported seeding chondrocytes in atelocollagen ${ }^{\circledR}$ (Koken Co Ltd, Tokyo, Japan), a type I collagen gel, and culturing the construct in a regular culture dish for 4 weeks for clinical use. They choose atelocollagen, from which telopeptides have been removed, because the antigenic determinants on the peptide chains of type I collagen reside mainly in the telopeptide regions [31, 90]. Atelocollagen has been used clinically in plastic surgery and dermatology [52]. Their in vitro and in vivo experimental [53, 57, 114] results support the hypothesis that transplanting chondrocytes cultured in atelocollagen gel are effective in repairing articular cartilage defects, not only in animals but also in humans, by maintaining the chondrocyte phenotype, reducing the risk of leakage, and distributing grafted cells evenly throughout the grafted site. The disadvantage is that the cell/gel construct needs to be implanted under a periosteal cover to prevent it from detaching.

\section{Hyaluronan-based polymer}

Hyaluronan (hyaluronic acid) is a major component of cartilage matrix. The construct, a naturally occurring and highly conserved glycosaminoglycan widely distributed in the body, has proven to be an ideal molecule for tissueengineering strategies in cartilage repair, given its impressive multi-functional activity in cartilage homeostasis [21, 68]. Hyaluronan containing scaffolds such as Hyaff- $11^{\circledR}$ (Fidia Advanced Biopolymers Laboratories, Abano Terme, Italy), an esterified derivative of hyaluronan, has a high degree of biocompatibility and can be used to culture chondrocytes in three-dimensional culture conditions that may effectively mimic an in vivo situation. It fully resorbs in 3 months with controllable degradation rates, with its main byproduct being hyaluronan, a sugar. Hyalograft ${ }^{\circledR} \mathrm{C}$ (Fidia Advanced Biopolymers Laboratories, Abano Terme, Italy) is a tissue-engineered graft consisting of autologous chondrocytes grown on a Hyaff-11 scaffold and a network of 20-lm-thick fibers with interstices of variable sizes. Articular cartilage is harvested from the patient and grown in a two-dimensional culture in vitro. Then the chondrocytes are absorbed onto a non-woven pad made of the benzyl ester of hyaluronic acid. The cells are seeded for 2 weeks on this hyaluronic acid scaffold at a density of 1 million cells per $\mathrm{cm}^{2}$, resulting in a total of 4 million seeded cells per $\mathrm{cm}^{2}$ per graft. After 2 weeks, this construct is implanted into the knee. In the majority of cases, no graft fixation is required. However, depending on the size and location of the defect, fibrin glue and/or sutures may be used to keep the graft in place.

In vitro studies have shown that chondrocytes grown in a three-dimensional matrix based on Hyaff-11 return to their phenotype in a time-dependent manner, thus restoring their capacity for secreting proteins and molecules characteristic of a hyaline cartilage $[1,15,40]$. In vivo studies in animal models have also shown that hyaluronan-based scaffolds seeded with autologous chondrocytes are useful for inducing formation of native, hyaline-like cartilage tissue with integration with the adjacent articular surface [39, 102, 103]. Extensive biocompatibility studies have demonstrated the safety of biomaterials containing Hyaff- 11 and their ability to be resorbed in the absence of an inflammatory response [18]. Furthermore, Hyaff-11-based tissue-engineered cartilage was assessed in an in vitro and in vivo setting with respect to structure, biochemical composition and mechanical behavior showing development and remodeling of tissue-engineered cartilage [110]. Hyalograft $\mathrm{C}$ was introduced into clinical use in 1999 [85]. Marcacci et al. [67] have reported the use of an arthroscopic surgical technique (Fig. 2).

\section{Fibrin}

Fibrin is a protein involved in the clotting of blood. It is formed by polymerization of fibrinogen in the presence of thrombin usually at the wound site. Fibrin has been an attractive biomaterial because it is biocompatible and biodegradable. Injectable fibrin-based gels or glues have been investigated for cartilage repair [48, 50, 60]. However, in vivo animal studies have shown that cell migration 


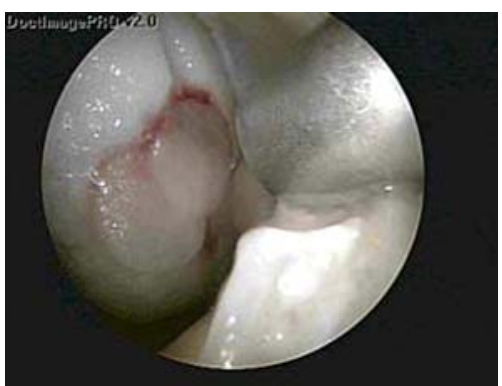

Fig. 2 Arthroscopic autologous chondrocyte implantation using Hyalograft C. Reprinted by permission from Marcacci et al. [67] "Arthroscopic autologous chondrocyte transplantation: Technical note. Knee Surg Sports Traumatol. Arthrosc 10:154-159"

and tissue repair using such material appears to be limited $[12,107]$. The mechanical stability of fibrin glue is questioned as well [107]; in addition, exogenous fibrin may trigger an immune response [58]. The action of fibrin glue on transplanted chondrocytes remains controversial. Therefore, so far fibrin glue has mainly been used clinically to secure other tissue-engineered cartilage [22, 85], or perichondrial scaffold grafts [9] etc. Visna et al. [115] has reported 1-year clinical results of tissue-engineered cartilage repair using fibrin glue $\left(\right.$ Tissucol $^{\circledR}$, BAXTER, Austria) compared to abrasion technique.

\section{Synthetic copolymer}

The bioresorbable polymer scaffold in clinical use is the copolymer of polyglycolic (PGA) / polylactic (PLA) acid (polyglactin, vicryl) and polydioxanone, which is used for tissue-engineered cartilage repair as Bio-Seed ${ }^{\circledR}-\mathrm{C}$ (Biotissue Technologies, Freiburg, Germany). The cartilage tissue-engineering graft Bio-Seed-C combines autologous chondrocytes with a fibrin gel matrix in a porous threedimensional textile polymer scaffold. The organotypic cell culture method with the cell-polymer tissues have been shown to allow the in vitro production of bioartificial cartilage for transplantation [17, 100]. Synthetic poly-ahydroxy ester substrates in the form of PGA and PLAbased scaffolds have also shown to enhance the promotion of proteoglycans, chondrocyte proliferation, differentiation and maturation in comparison to collagen-based scaffolds [38]. Gel-like matrices such as fibrin allow even distribution of a large number of vital chondrocytes within the graft and promote chondrocyte differentiation as well as the formation of a cartilaginous repair tissue, while the polymer scaffold mediates initial biomechanical stability and allows easy handling of the graft by the surgeon [56]. Animal studies on rabbits and horses have shown formation of a cartilaginous tissue and good integration into the surrounding host tissue with firm bonding of the graft to the adjacent cartilage and the underlying subchondral bone $[4,86]$. Such bioresorbable scaffold material has good immunogenic compatibility, and is frequently used clinically as suture material (polyglactin, vicryl). Various in vitro and animal studies have shown that the scaffold supports cartilaginous tissue development with no signs of necrosis, apoptosis, or abnormal tissue reaction $[4,56,84$, 97]. Erggelet et al. [28] has reported a technical note of using the polymer fleece 2 -mm thick, loaded with $5 \times 10^{6}$ chondrocytes in a fibrin gel by arthroscopic technique in 2003. Further, Ossendorf et al. [84] has already shown 2-year clinical results on the use of the two component gel-polymer scaffold.

\section{Clinical outcomes of articular cartilage repair with scaffolds}

The inclusion criteria for clinical studies on scaffold techniques were prospective or retrospective studies with a clinical outcome. Fourteen studies were included in this review based on the inclusion criteria (Tables 1,2). Of these, eight studies have been published including hyaluronan-based scaffold (Hyalograft C) [36, 65, 68, 69, 71, 82, 85, 112]. Three studies have assessed the outcome of MACI with a bilayer collagen type I-III membrane [5, 6, 22]. The remaining three studies have assessed the outcome with a collagen type I gel, fibrin glue, and synthetic copolymer [83, 84, 115]. Only very limited number of prospective, randomized or non-randomized comparative studies have been published $[5,65,115]$.The majority of the published studies had no control group, represented case series or retrospective level IV studies. As mentioned, our literature searches are based on the articles published between 1 January 1966, and 1 March 2008. Accordingly, the most important limitation of this study is the limitation of the already existing studies.

\section{Clinical and functional scores}

Encouraging clinical results have been published in terms of various subjective and objective scores in all 14 available studies including arthroscopic technique [69] and patello-femoral joint injury [36] (Table 1). According to a prospective, randomized study by Visna et al. [115], the use of tissue-engineered cartilage based on fibrin glue was superior to abrasion technique as measured by the International Knee Documentation Committee (IKDC) subjective score, Lysholm score, and Tengner activity score 1 year after surgery. However, Manfredini et al. [65] showed no significant differences in International 


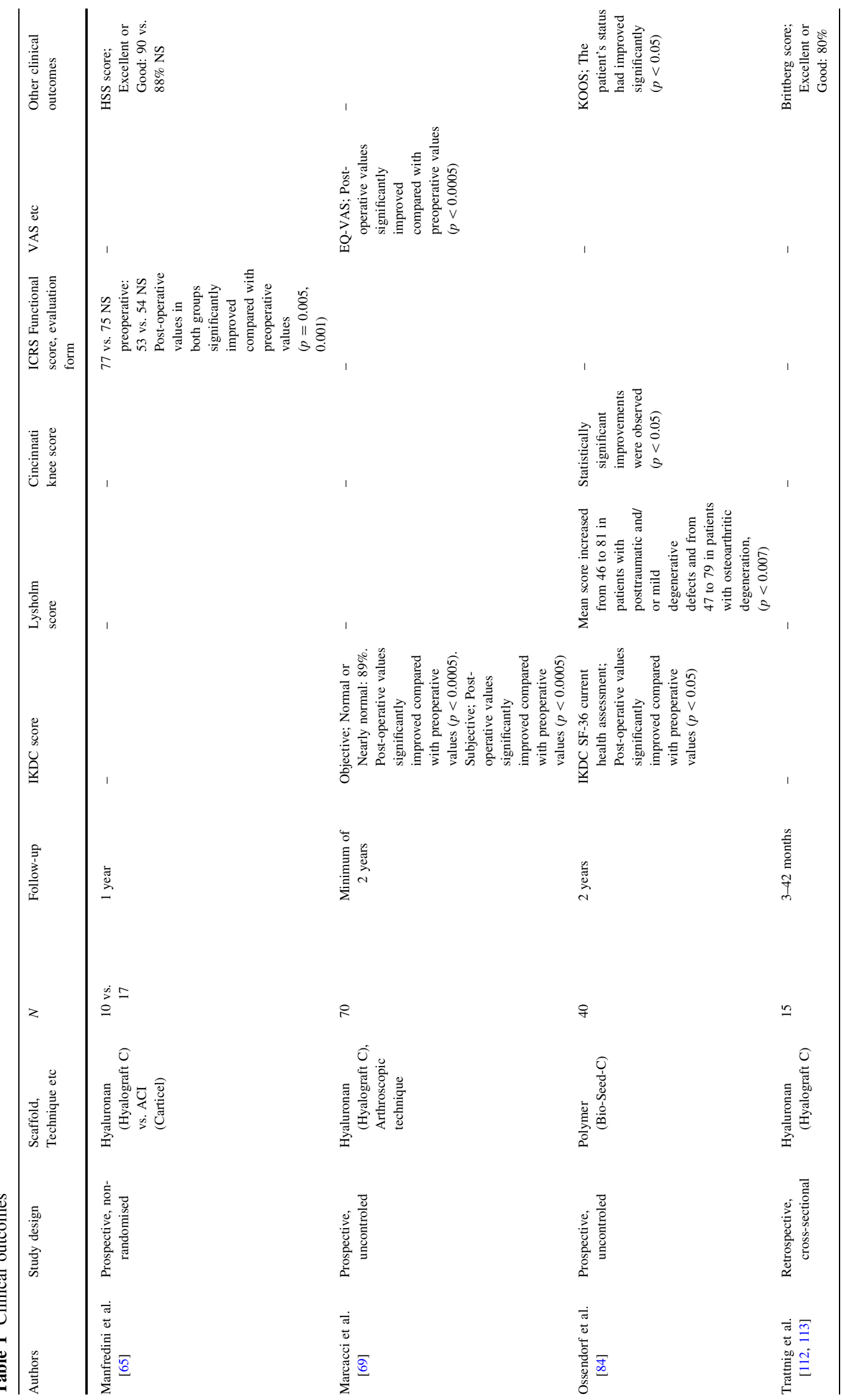




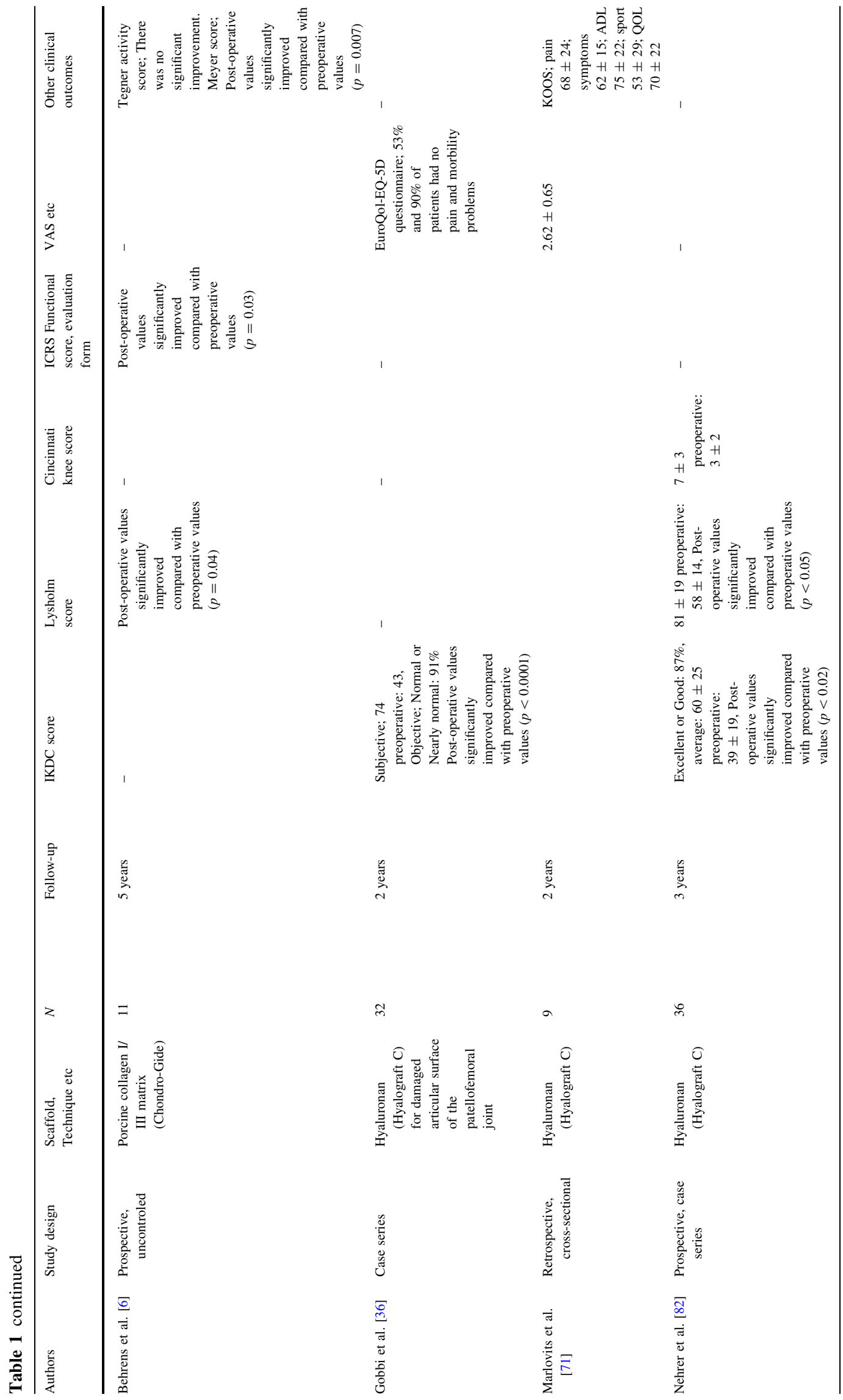




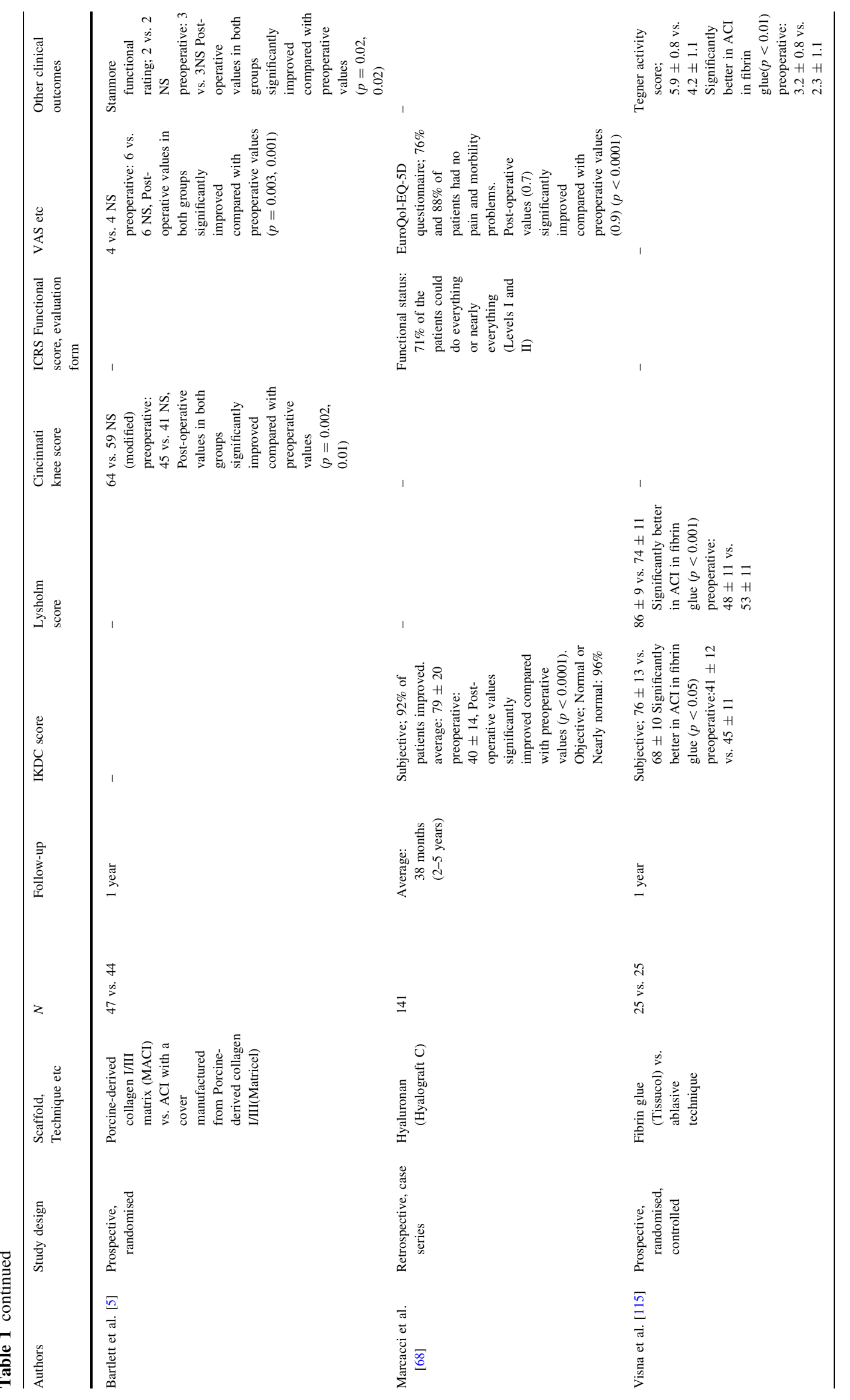




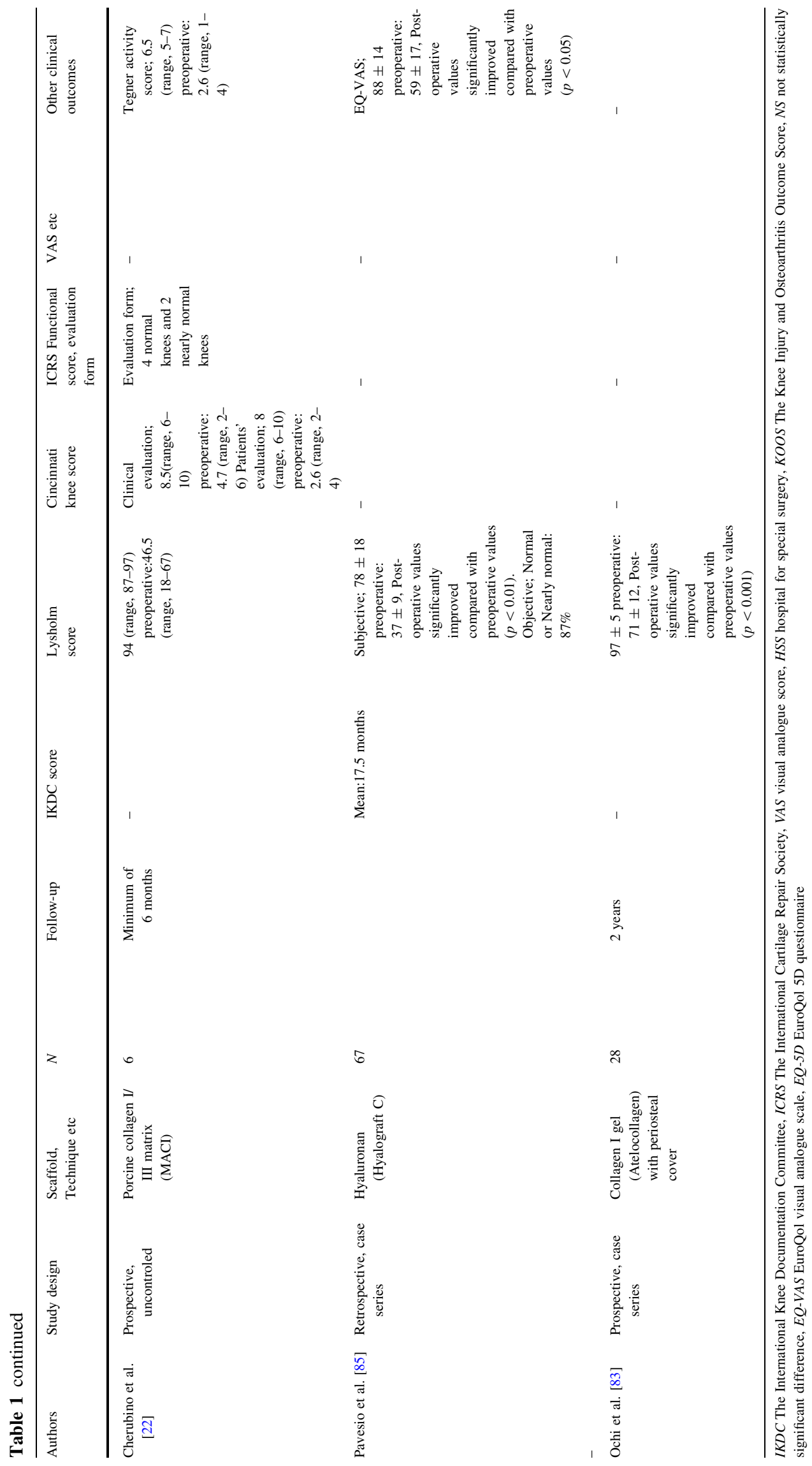


Cartilage Repair Society score (ICRS) score and the Hospital for Special Surgery (HSS) score between patients with Hyalograft $\mathrm{C}$ and those undergoing ACI procedure. According to Bartlett et al. [5], no differences were found in the clinical outcomes such as the Cincinnati Knee Rating System, Stanmore functional rating system, and visual analogue score between standard ACI procedure using a collagen membrane as cover and MACI. The follow-up periods in these comparative studies were short (1 year).

In a prospective study, 5 years after transplantation of cell seeded collagen grafts, 8 of 11 patients rated the knee function better than pre-operatively, and the clinical evaluation showed significant improvement in the Meyers score, the Lysholm score and ICRS score [6]. In a multicenter retrospective cohort study using Hyalograft $\mathrm{C}$ with a follow-up from 2 to 5 years, $91.5 \%$ of 141 patients improved according to the IKDC subjective evaluation, with patients who had traumatic injuries and osteochondritis dissecans (OCD) reported better improvement than those who had degenerative lesions [68].

The clinical outcome with MACI membrane by Bartlett et al. [5] was better in the group of patients aged under 35 years, compared with those aged over 35 years. Patients who had been treated for lesions larger than $5 \mathrm{~cm}^{2}$ in size had poorer clinical outcomes than those with smaller lesions, although the differences were not statistically significant. Nehrer et al. [82] have also showed that patients with Hyalograft $\mathrm{C}$ below 30 years of age with single lesions showed significantly better improvements compared with those over 30 years with multiple defects. They suggest that implantation of Hyalograft $\mathrm{C}$ in older patients or those with multiple defects should only be carried out in selected patients with high compliance and lesser expectations with regard to physical activity. Regardless of the type of scaffolds, the use of tissueengineered grafts based on these scaffolds appears to be as effective as conventional ACI, although none of these methods so far have been shown to be better.

\section{Complications, graft failures}

There are only few serious adverse events reported in the literature (Table 2). The rate of superficial infection of patients ranges from 0 to $2 \%$, which is equivalent to that of patients using the convensional ACI technique [7, 11, $14,26,30,37,45,47,51,61,62,64,73-77,87-89$, 119]. There are no patients of septic arthritis, which ranged from $0-3 \%$ of patients using the convensional ACI technique $[7,11,14,26,30,37,45,47,51,61,62$, $64,73-77,87-89,119]$. Apart from two studies reporting the use of periosteal flaps $[83,85]$, the frequency of complications such as arthrofibrosis or graft failure appear to be lower $(0-18 \%)$ than those reported to occur in $3-36 \%$ of patients using the conventional ACI technique $[7,11,14,26,30,37,45,47,51,61,62,64,73-$ $77,87-89,119]$. The frequency of reoperations related to the implantation is also lower $(0-16 \%)$ than those reported to occur in $2-36 \%$ of patients using the conventional $\mathrm{ACI}$ technique $[7,11,14,26,30,37,45,47$, 51, 61, 62, 64, 73-77, 87-89, 119]. Complications known to be associated with ACI include adhesions, arthrofibrosis, periosteal hypertrophy, and graft failure. Using scaffold techniques, periosteal hypertrophy does not occur due to the fact that in the majority of procedures, periosteum is not used. Periosteal hypertrophy is a common complication of ACI $[11,37,42,45,61,73,74,76,78$, 87, 119]. According to the only study, which compares the results of MACI (Hyalograft C) and conventional ACI (Carticel ${ }^{\circledR}$; Genzyme, Cambridge, Massachusetts, USA) by Manfredini et al. [65], however, neither the patients with Hyalograft $\mathrm{C}$ nor those with conventional ACI reported any serious complications. This literature review clearly shows the need for prospective, randomized studies with sufficient number of patients. At this stage of development it appears that new techniques with scaffolds seem to reduce complications or graft failures caused by a periosteal flap.

\section{Arthroscopic and histological findings}

Nine of the fourteen articles have reported second-look arthroscopic and histological findings (Table 2) [5, 6, 36, 68, $69,83-85,115]$. These arthroscopic assessments indicated that $66-100 \%$ of available patients had a normal or nearly normal outcome in the ICRS visual score or Brittberg scale. Histological analysis have shown that the frequency of hyaline-like repair with good integration into the surrounding tissue was ranged $0-100 \%$ (2-22 biopsies, 3-30 months after operation). The wide difference of hyaline-like repair ratio between these published studies may be due to the differences in the number of biopsies and the time of biopsies. It is well known that the validity and significance of a biopsy is limited by the number of biopsies taken and the time after surgery, and that a biopsy result presents rather a trend [6]. ACI using periosteum has consistently reported more than $34 \%$ of the biopsy specimens had at least some hyaline cartilage present, although few were composed totally of hyaline cartilage $[10,11,37,44-47,51,61,87,88$, $95,109]$. There is not sufficient evidence to state that scaffold methods result in homogeneous distribution of cells in the scaffold, maintenance of the chondrocyte phenotype and more hyaline cartilage, all three potential advantages over ACI. Despite many positive clinical results published, the 


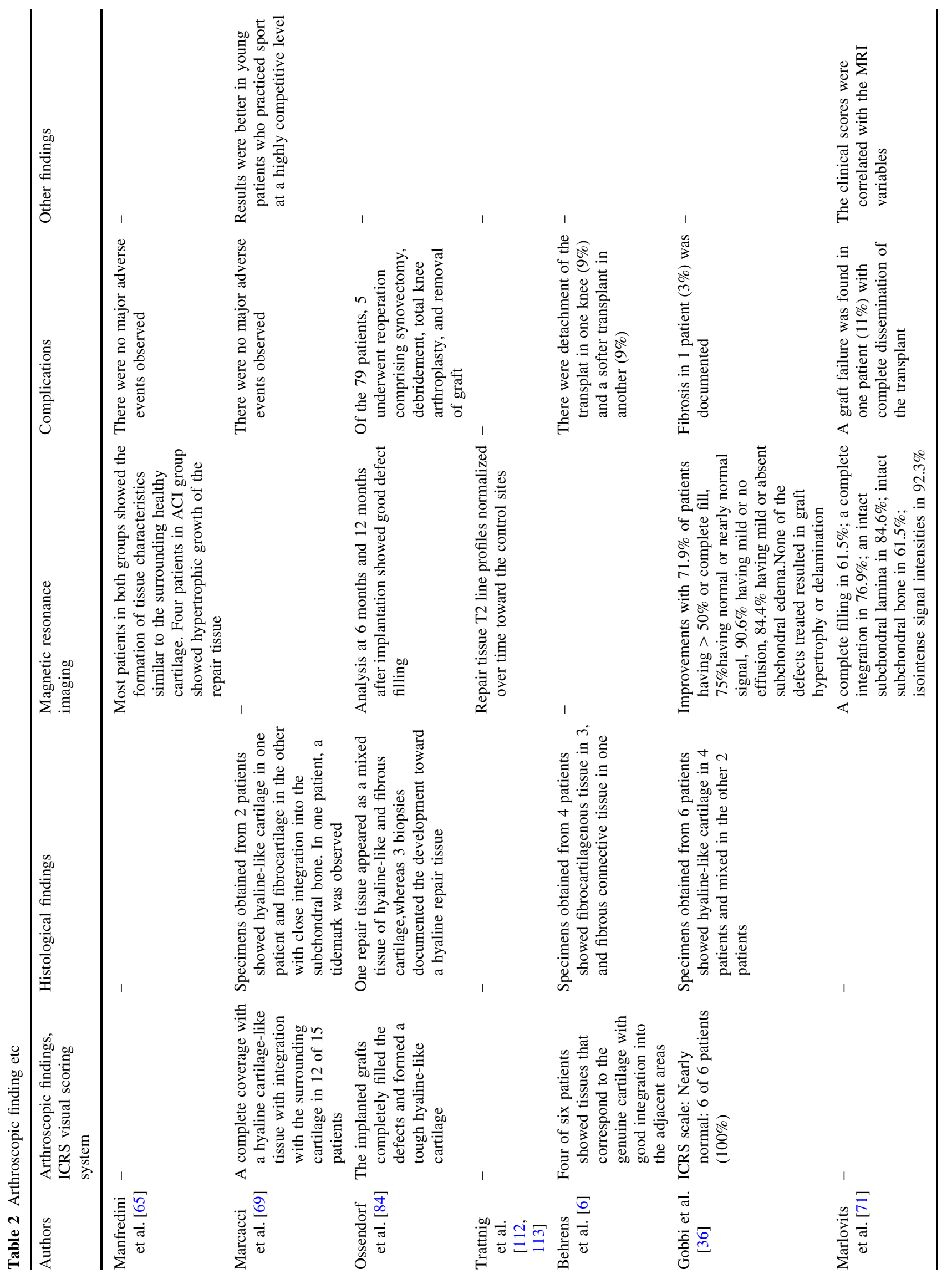




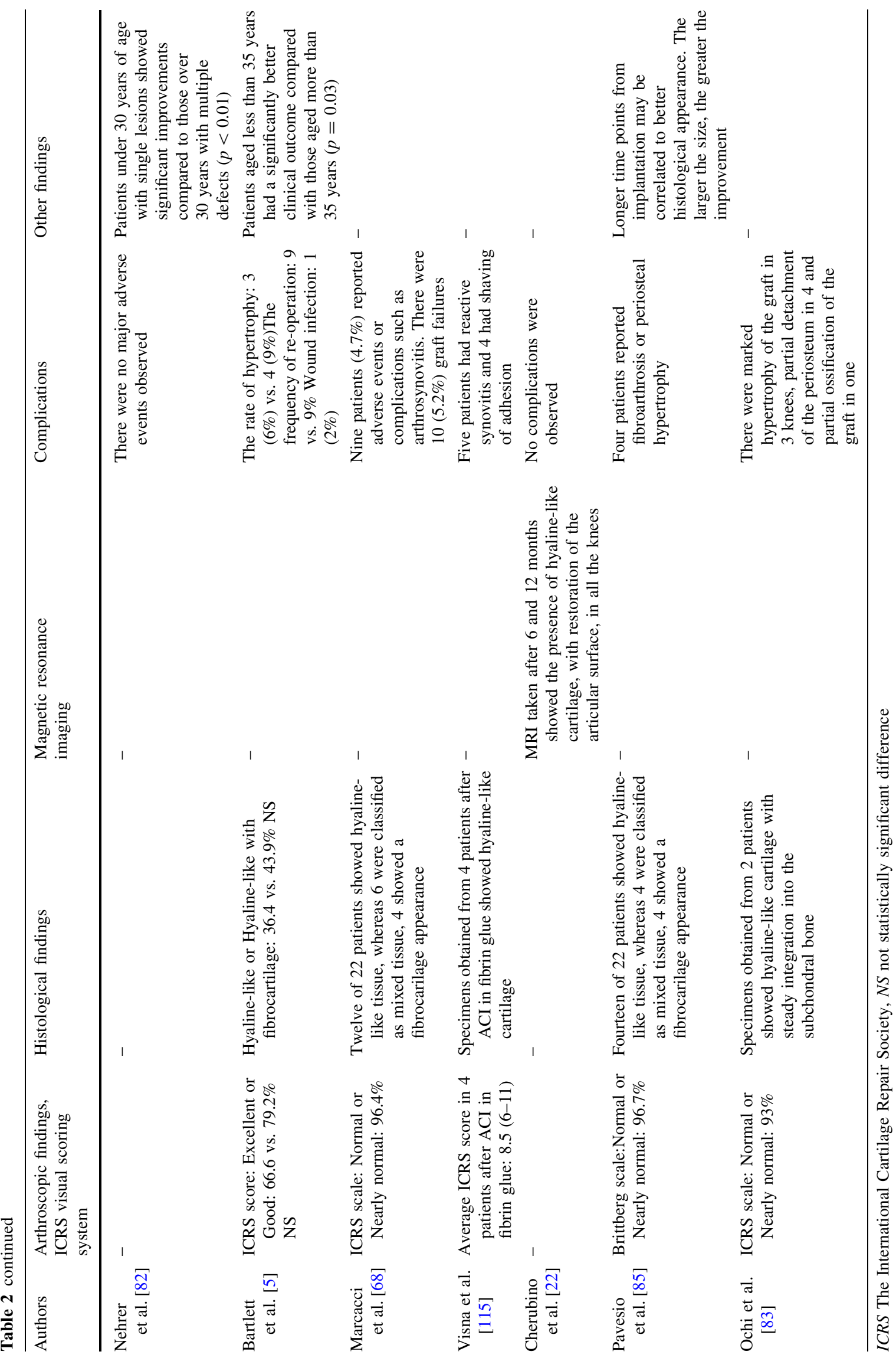


studies have not been able to demonstrate a complete healing with normal hyaline articular cartilage.

Follow-up biopsies from conventional ACI grafts showed the four cartilage layers composed of fibrous periosteal remnant cover, transitional repair tissue, deep hyaline-like repair tissue, and calcified layer [74, 94]. On the other hand, histological evaluation of the samples of fibrin scaffold by Visna et al. [115] demonstrated only two layers of hyaline-like cartilage and calcified layer. Differing histological findings between the conventional ACI and the scaffold technique can be explained by the different surgical technique, where the first two layers in ACI technique developed as a consequence of periostal use for chondrocyte fixation [115].

Hollander et al. [49] reported a detailed study of the maturation of Hyalograft $\mathrm{C}$ once implanted into humans. They has shown that hyaline cartilage regeneration can be observed less than one year after implantation of Hyalograft $\mathrm{C}$ and that there is progressive maturation of the implants, even in joints showing signs of osteoarthritis. This outcome was observed in 10 of 23 patients, whereas in a further 10 patients, the repair tissue was fibro-cartilage, and in the remaining 3 , there was a mixed type of cartilage [49].

From a cohort of 56 MACI patients, Zheng et al. [120] examined the phenotype of chondrocytes seeded on type I/ III collagen scaffold, and conducted progressive histological assessment over a period of 6 months. Their data showed that chondrocytes on the collagen scaffold appeared spherical, well integrated into the matrix, and maintained the chondrocyte phenotype as evidenced by aggrecan, type II collagen, and S-100 expression. Progressive histological evaluation of the biopsies showed the formation of cartilage-like tissue as early as 21 days, and $75 \%$ hyaline-like cartilage regeneration after 6 months. While fibrin sealant appeared to act as an adhesive substance for the seeded ACI-Maix collagen scaffold, it also facilitated the maturation of the implanted chondrocytes into functional cartilage [120].

According to Pavesio et al. [85], comparison of the clinical outcomes with arthroscopic assessment and histological findings showed that hyaline-like regenerated tissue correlated with the most favorable clinical results. However, Behrens et al. [6] demonstrated that some patients can have a good clinical outcome despite generating fibrocartilage at the repair site. The correlation between clinical outcome and histologic grading remains controversial.

\section{Magnetic resonance imaging}

Magnetic resonance imaging (MRI) is useful for the evaluation of the morphologic status of the repair tissue [91,
93]. This method can be considered as a noninvasive alternative to second-look arthroscopy. Current MRI techniques such as high-resolution, T2 mapping, and T1 mapping using delayed gadolinium-enhanced MRI (dGEMRIC) have significantly improved during recent years [111-113]. Six of the fourteen studies have published MRI findings (Table 2) [22, 36, 65, 71, 84, 112]. The MRI analysis at 6, 12, 24 months after implantation has shown good defect filling with good integration into the surrounding tissue in more than $60 \%$ of patients [22, 36, 65, $71,84]$. In addition, repair tissue has shown a gradual maturation over time [36, 111, 112]. Similar findings have been reported in studies with conventional ACI [13, 44, 46, 89, 95, 108, 109]. Marlovits et al. [70] found using highresolution MRI that the implantation and fixation of chondrocytes seeded on type I/III collagen scaffold with fibrin glue and with no further surgical fixation leads to a high attachment rate (88\%) 35 days after the implantation. According to the study that compared the results of Hyalograft $\mathrm{C}$ with those of Carticel by Manfredini et al. [65], MRI analysis did not reveal any significant differences, although the images of patients with Carticel showed a greater tendency towards hypertrophic growth of the repair tissue probably due to periosteal hypertrophy. Some authors $[65,71]$ have reported a significant correlation between the clinical outcome and the MRI analysis scores.

\section{Conclusion and future considerations on scaffolds for cartilage repair}

The tissue-engineering methods with scaffolds including the arthroscopic technique are less invasive because there is no need to harvest periosteum. These methods reduce surgical time, morbidity, and risks of periosteal hypertrophy and postsurgical adhesions substantially. The technical and theoretical advantages of scaffold techniques have led to the technique being favored by surgeons performing chondrocyte implantation. However, in this review of the short- or mid-term, clinical and histological results published by various studies, none of these methods were judged to be better than conventional ACI. In addition, there was no obvious ranking among the scaffolds available for clinical use at the present time. There is probably not an even distribution of chondrocytes. These methods seem to promote chondrocyte differentiation and formation of cartilage matrix, but so far, they have not resulted in improved clinical results.

The ultimate aim of cartilage treatment is the restoration of normal knee function by regeneration of hyaline cartilage, and to achieve a complete integration of the new cartilage to the surrounding cartilage and underlying 
bone. Promising development is underway with regards to cell-based techniques in combination with scaffolds, growth factors and possibly gene therapy. Unfortunately, this effort has not been followed by appropriate or sufficient clinical studies to assess these new methods or compare them with available procedures.

The methodological level of the clinical papers is in general low. Jacobsen et al. [54] showed very low methodological quality of most studies on cartilage repair. So far, only three prospective, randomized or non-randomized comparative studies have been published. The generally low methodological quality of many studies shows that caution is required when interpreting results after surgical cartilage repair. Firm recommendations on which cartilage repair procedure is to be preferred is currently not known on the basis of these studies.

Valid clinical answers in this field will only be the results of a combination of randomized control trials (RCTs). Further, long-term follow up is needed to determine whether articular cartilage repair with scaffold is a valid alternative as first line of treatment of larger cartilage defects compared with ACI.

Open Access This article is distributed under the terms of the Creative Commons Attribution Noncommercial License which permits any noncommercial use, distribution, and reproduction in any medium, provided the original author(s) and source are credited.

\section{References}

1. Aigner J, Tegeler J, Hutzler P, Campoccia D, Pavesio A, Hammer C, Kastenbauer E, Naumann A (1998) Cartilage tissue engineering with novel nonwoven structured biomaterial based on hyaluronic acid benzyl ester. J Biomed Mater Res 42:172181

2. Aroen A, Loken S, Heir S, Alvik E, Ekeland A, Granlund OG, Engebretsen L (2004) Articular cartilage lesions in 993 consecutive knee arthroscopies. Am J Sports Med 32:211-215

3. Atala A, Cima LG, Kim W, Paige KT, Vacanti JP, Retik AB, Vacanti CA (1993) Injectable alginate seeded with chondrocytes as a potential treatment for vesicoureteral reflux. J Urol 150:745-747

4. Barnewitz D, Endres M, Kruger I, Becker A, Zimmermann J, Wilke I, Ringe J, Sittinger M, Kaps C (2006) Treatment of articular cartilage defects in horses with polymer-based cartilage tissue engineering grafts. Biomaterials 27:2882-2889

5. Bartlett W, Skinner JA, Gooding CR, Carrington RW, Flanagan AM, Briggs TW, Bentley G (2005) Autologous chondrocyte implantation versus matrix-induced autologous chondrocyte implantation for osteochondral defects of the knee: a prospective, randomised study. J Bone Joint Surg Br 87:640-645

6. Behrens P, Bitter T, Kurz B, Russlies M (2006) Matrix-associated autologous chondrocyte transplantation/implantation (MACT/MACI)-5-year follow-up. Knee 13:194-202

7. Bentley G, Biant LC, Carrington RWT, Akmal M, Goldberg A, Williams AM, Skinner JA, Pringle J (2003) A prospective, randomized comparison of autologous chondrocyte implantation versus mosaicplasty for ostechondral defects of the knee. J Bone Joint Surg Br 85:223-230
8. Benya PD, Shaffer JD (1982) Dedifferentiated chondrocytes re-express the differentiated collagen phenotype when cultured in agarose gels. Cell 30:215-224

9. Bouwmeester SJ, Beckers JM, Kuijer R, van der Linden AJ, Bulstra SK (1997) Long-term results of rib perichondrial grafts for repair of cartilage defects in the human knee. Int Orthop $21: 313-317$

10. Briggs TWR, Mahroof S, David LA, Flannelly J, Pringle J, Bayliss M (2003) Histological evaluation of chondral defects after autologous chondrocyte implantation of the knee. J Bone Joint Surg Br 85:1077-1083

11. Brittberg M, Lindahl A, Nilsson A, Ohlsson C, Isaksson O, Peterson L (1994) Treatment of deep cartilage defects in the knee with autologous chondrocyte transplantation. N Eng J Med 331:889-895

12. Brittberg M, Sjogren-Jansson E, Lindahl A, Peterson L (1997) Influence of fibrin sealant (Tisseel) on osteochondral defect repair in the rabbit knee. Biomaterials 18:235-242

13. Brown WE, Potter HG, Marx RG, Wickiewicz TL, Warren RF (2004) Magnetic resonance imaging appearance of cartilage repair in the knee. Clin Orthop Relat Res 422:214-223

14. Browne JE, Anderson AF, Arciero R, Mandelbaum B, Moseley JB Jr, Micheli LJ, Fu F, Erggelet C (2005) Clinical outcome of autologous chondrocyte implantation at 5 years in US subjects. Clin Orthop Relat Res 436:237-245

15. Brun P, Abatangelo G, Radice M, Zacchi V, Guidolin D, Daga Gordini D, Cortivo R (1999) Chondrocyte aggregation and reorganization into three-dimensional scaffolds. J Biomed Mater Res 46:337-346

16. Buckwalter JA, Mankin HJ (1998) Articular cartilage: tissue design and chondrocyte-matrix interactions. Instr Course Lect 47:477-486

17. Bujia J, Sittinger M, Minuth WW, Hammer C, Burmester G, Kastenbauer E (1995) Engineering of cartilage tissue using bioresorbable polymer fleeces and perfusion culture. Acta Otolaryngol 115:307-310

18. Campoccia D, Doherty P, Radice M, Brun P, Abatangelo G, Williams DF (1998) Semisynthetic resorbable materials from hyaluronan esterification. Biomaterials 19:2101-2127

19. Caplan AI, Elyaderani M, Mochizuki Y, Wakitani S, Goldberg VM (1997) Principles of cartilage repair and regeneration. Clin Orthop Relat Res 342:254-269

20. Chaipinyo K, Oakes BW, Van Damme MP (2004) The use of debrided human articular cartilage for autologous chondrocyte implantation: maintenance of chondrocyte differentiation and proliferation in type I collagen gels. J Orthop Res 22:446-455

21. Chen WY, Abatangelo G (1999) Functions of hyaluronan in wound repair. Wound Repair Regen 7:79-89

22. Cherubino P, Grassi FA, Bulgheroni P, Ronga M (2003) Autologous chondrocyte implantation using a bilayer collagen membrane: a preliminary report. J Orthop Surg (Hong Kong) $11: 10-15$

23. Chu CR, Coutts RD, Yoshioka M, Harwood FL, Monosov AZ, Amiel D (1995) Articular cartilage repair using allogeneic perichondrocyte-seeded biodegradable porous polylactic acid (PLA): a tissue-engineering study. J Biomed Mater Res 29:1147-1154

24. Chung KM, Salkin LM, Stein MD, Freedman AL (1990) Clinical evaluation of a biodegradable collagen membrane in guided tissue regeneration. J Periodontol 61:732-736

25. Dorotka R, Windberger U, Macfelda K, Bindreiter U, Toma C, Nehrer S (2005) Repair of articular cartilage defects treated by microfracture and a three-dimensional collagen matrix. Biomaterials 26:3617-3629

26. Dozin B, Malpeli M, Cancedda R, Bruzzi P, Calcagno S, Molfetta L, Priano F, Kon E, Marcacci M (2005) Comparative 
evaluation of autologous chondrocyte implantation and mosaicplasty. A multicentered randomized clinical trial. Clin J Sport Med 15:220-226

27. Ehlers EM, Fuss M, Rohwedel J, Russlies M, Kühnel W, Behrens P (1999) Development of a biocomposite to fill out articular cartilage lesions. Light, scanning and transmission electron microscopy of sheep chondrocytes cultured on a collagen I/III sponge. Ann Anat 181:513-518

28. Erggelet C, Sittinger M, Lahm A (2003) The arthroscopic implantation of autologous chondrocytes for the treatment of full-thickness cartilage defects of the knee joint. Arthroscopy 19:108-110

29. Frenkel SR, Toolan B, Menche D, Pitman MI, Pachence JM (1997) Chondrocyte transplantation using a collagen bilayer matrix for cartilage repair. J Bone Joint Surg Br 79:831-836

30. Fu FH, Zurakowski D, Browne JE, Mandelbaum B, Erggelet C, Moseley JB Jr, Anderson AF, Micheli LJ (2005) Autologous chondrocyte implantation versus debridement for treatment of full-thickness chondral defects of the knee: an observational cohort study with 3-year follow-up. Am J Sports Med 33: $1658-1666$

31. Furthmayr H, Timpl R (1976) Immunochemistry of collagens and procollagens. Int Rev Connect Tissue Res 7:61-99

32. Furukawa T, Eyre DR, Koide S, Glimcher MJ (1980) Biochemical studies on repair cartilage resurfacing experimental defects in the rabbit knee. J Bone Joint Surg Am 62:79-89

33. Fuss M, Ehlers EM, Russlies M, Rohwedel J, Behrens P (2000) Characteristics of human chondrocytes, osteoblasts and fibroblasts seeded onto a type I/III collagen sponge under different culture conditions. A light, scanning and transmission electron microscopy study. Ann Anat 182:303-310

34. Gigante A, Bevilacqua C, Cappella M, Manzotti S, Greco F (2003) Engineered articular cartilage: influence of the scaffold on cell phenotype and proliferation. J Mater Sci: Mater Med 14:713-716

35. Gigante A, Bevilacqua C, Ricevuto A, Mattioli-Belmonte M, Greco F (2007) Membrane-seeded autologous chondrocytes: cell viability and characterization at surgery. Knee Surg Sports Traumatol Arthrosc 15:88-92

36. Gobbi A, Kon E, Berruto M, Francisco R, Filardo G, Marcacci M (2006) Patellofemoral full-thickness chondral defects treated with Hyalograft-C: a clinical, arthroscopic, and histologic review. Am J Sports Med 34:1763-1773

37. Gooding CR, Bartlett W, Bentley G, Skinner JA, Carrington R, Flanagan A (2006) A prospective, randomised study comparing two techniques of autologous chondrocyte implantation for osteochondral defects in the knee: Periosteum covered versus type I/III collagen covered. Knee 13:203-210

38. Grande DA, Halberstadt C, Naughton G, Schwartz R, Manji R (1997) Evaluation of matrix scaffolds for tissue engineering of articular cartilage grafts. J Biomed Mater Res 34:211-220

39. Grigolo B, Roseti L, Fiorini M, Fini M, Giavaresi G, Aldini N, Giardino R, Facchini A (2001) Transplantation of chondrocytes seeded on a hyaluronan derivative (hyaff-11) into cartilage defects in rabbits. Biomaterials 22:2417-2424

40. Grigolo B, Lisignoli G, Piacentini A, Fiorini M, Gobbi P, Mazzotti G, Duca M, Pavesio A, Facchini A (2002) Evidence for redifferentiation of human chondrocytes grown on a hyaluronan-based biomaterial (HYAff 11): molecular, immunohistochemical and ultrastructural analysis. Biomaterials 23:1187-1195

41. Guo J, Jourdian GW, MacCallum DK (1989) Culture and growth characteristics of chondrocytes encapsulated in alginate beads. Connect Tissue Res 19:277-297

42. Haddo O, Mahroof S, Higgs D, David L, Pringle J, Bayliss M, Cannon SR, Briggs TW (2004) The use of chondrogide membrane in autologous chondrocyte implantation. Knee 11:51-55
43. Häuselmann HJ, Fernandes RJ, Mok SS, Schmid TM, Block JA, Aydelotte MB, Kuettner KE, Thonar EJ (1994) Phenotypic stability of bovine articular chondrocytes after long-term culture in alginate beads. J Cell Sci 107:17-27

44. Henderson IJ, Tuy B, Connell D, Oakes B, Hettwer WH (2003) Prospective clinical study of autologous chondrocyte implantation and correlation with MRI at three and 12 months. J Bone Joint Surg Br 85:1060-1066

45. Henderson I, Tuy B, Oakes B (2004) Reoperation after autologous chondrocyte implantation. Indications and findings. J Bone Joint Surg Br 86:205-211

46. Henderson I, Francisco R, Oakes B, Cameron J (2005) Autologous chondrocyte implantation for treatment of focal chondral defects of the knee-a clinical, arthroscopic, MRI and histologic evaluation at 2 years. Knee 12:209-216

47. Henderson I, Lavigne P, Valenzuela H, Oakes B (2007) Autologous chondrocyte implantation: superior biologic properties of hyaline cartilage repairs. Clin Orthop Relat Res 455:253-261

48. Hendrickson DA, Nixon AJ, Grande DA, Todhunter RJ, Minor RM, Erb H, Lust G (1994) Chondrocyte-fibrin matrix transplants for resurfacing extensive articular cartilage defects. J Orthop Res 12:485-496

49. Hollander AP, Dickinson SC, Sims TJ, Brun P, Cortivo R, Kon E, Marcacci M, Zanasi S, Borrione A, De Luca C, Pavesio A, Soranzo C, Abatangelo G (2006) Maturation of tissue engineered cartilage implanted in injured and osteoarthritic human knees. Tissue Eng 12:1787-1798

50. Homminga GN, Buma P, Koot HW, van der Kraan PM, van den Berg WB (1993) Chondrocyte behaviour in fibrin glue in vitro. Acta Orthop Scand 64:441-445

51. Horas U, Pelinkovic D, Herr G, Aigner T, Schnettler R (2003) Autologous chondrocyte implantation and osteochondral cylinder transplantation in cartilage repair of the knee joint. J Bone Joint Surg Am 85:185-192

52. Ishihara T, Ono T (2001) Analysis of the vascularity of an atelocollagen sponge substitute dermis in the human. J Dermatol 28:360-368

53. Iwasa J, Ochi M, Uchio Y, Katsube K, Adachi N, Kawasaki K (2003) Effects of cell density on proliferation and matrix synthesis of chondrocytes embedded in atelocollagen gel. Artif Organs 27:249-255

54. Jakobsen RB, Engebretsen L, Slauterbeck JR (2005) An analysis of the quality of cartilage repair studies. J Bone Joint Surg Am 87:2232-2239

55. Jones CW, Willers C, Keogh A, Smolinski D, Fick D, Yates PJ, Kirk TB, Zheng MH (2007) Matrix-induced autologous chondrocyte implantation in sheep: objective assessments including confocal arthroscopy. J Orthop Res 27(26):292-303

56. Kaps C, Frauenschuh S, Endres M, Ringe J, Haisch A, Lauber J, Buer J, Krenn V, Haupl T, Burmester GR, Sittinger M (2006) Gene expression profiling of human articular cartilage grafts generated by tissue engineering. Biomaterials 27:36173630

57. Katsube K, Ochi M, Uchio Y, Maniwa S, Matsusaki M, Tobita M, Iwasa J (2000) Repair of articular cartilage defects with cultured chondrocytes in atelocollagen gel: comparison with cultured chondrocytes in suspension. Arch Orthop Trauma Surg 120:121-127

58. Kawabe N, Yoshinao M (1991) The repair of full-thickness articular cartilage defects. Immune responses to reparative tissue formed by allogeneic growth plate chondrocyte implants. Clin Orthop Relat Res 268:279-293

59. Kimura T, Yasui N, Ohsawa S, Ono K (1984) Chondrocytes embedded in collagen gels maintain cartilage phenotype during long-term cultures. Clin Orthop Relat Res 186:231-239 
60. Kirilak Y, Pavlos NJ, Willers CR, Han R, Feng H, Xu J, Asokananthan N, Stewart GA, Henry P, Wood D, Zheng MH (2006) Fibrin sealant promotes migration and proliferation of human articular chondrocytes: possible involvement of thrombin and protease-activated receptors. Int J Mol Med 17:551-558

61. Knutsen G, Engebretsen L, Ludvigsen TC, Drogset JO, Grøntvedt T, Solheim E, Strand T, Roberts S, Isaksen V, Johansen O (2004) Autologous chondrocyte implantation compared with microfracture in the knee. A randomized trial. J Bone Joint Surg Am 86:455-464

62. Knutsen G, Drogset JO, Engebretsen L, Grontvedt T, Isaksen V, Ludvigsen TC, Roberts S, Solheim E, Strand T, Johansen O (2007) A randomized trial of autologous chondrocyte implantation with microfracture. Findings at five years. J Bone Joint Surg Am 89:2105-2112

63. Krishnan SP, Skinner JA, Carrington RW, Flanagan AM, Briggs TW, Bentley G (2006) Collagen-covered autologous chondrocyte implantation for osteochondritis dissecans of the knee: two- to seven-year results. J Bone Joint Surg Br 88:203-205

64. Mandelbaum B, Browne JE, Fu F, Micheli LJ, Moseley JB Jr, Erggelet C, Anderson AF (2007) Treatment outcomes of autologous chondrocyte implantation for full-thickness articular cartilage defects of the trochlea. Am J Sports Med 35:915921

65. Manfredini M, Zerbinati F, Gildone A, Faccini R (2007) Autologous chondrocyte implantation: a comparison between an open periosteal-covered and an arthroscopic matrix-guided technique. Acta Orthop Belg 73:207-218

66. Mankin HJ (1982) The response of articular cartilage to mechanical injury. J Bone Joint Surg Am 64:460-466

67. Marcacci M, Zaffagnini S, Kon E, Visani A, Iacono F, Loreti I (2002) Arthroscopic autologous chondrocyte transplantation: technical note. Knee Surg Sports Traumatol Arthrosc 10:154159

68. Marcacci M, Berruto M, Brocchetta D, Delcogliano A, Ghinelli D, Gobbi A, Kon E, Pederzini L, Rosa D, Sacchetti GL, Stefani G, Zanasi S (2005) Articular cartilage engineering with Hyalograft C: 3-year clinical results. Clin Orthop Relat Res 435:96-105

69. Marcacci M, Kon E, Zaffagnini S, Filardo G, Delcogliano M, Neri MP, Iacono F, Hollander AP (2007) Arthroscopic second generation autologous chondrocyte implantation. Knee Surg Sports Traumatol Arthrosc 15:610-619

70. Marlovits S, Striessnig G, Kutscha-Lissberg F, Resinger C, Aldrian SM, Vécsei V, Trattnig S (2005) Early postoperative adherence of matrix-induced autologous chondrocyte implantation for the treatment of full-thickness cartilage defects of the femoral condyle. Knee Surg Sports Traumatol Arthrosc 13:451457

71. Marlovits S, Singer P, Zeller P, Mandl I, Haller J, Trattnig S (2006) Magnetic resonance observation of cartilage repair tissue (MOCART) for the evaluation of autologous chondrocyte transplantation: determination of interobserver variability and correlation to clinical outcome after 2 years. Eur J Radiol 57:16-23

72. Masuda K, Sah RL, Hejna MJ, Thonar EJ (2003) A novel twostep method for the formation of tissue-engineered cartilage by mature bovine chondrocytes: the alginate-recovered-chondrocyte (ARC) method. J Orthop Res 21:139-148

73. Micheli LJ, Browne JE, Erggelet C, Fu F, Mandelbaum B, Moseley JB, Zurakowski D (2001) Autologous chondrocyte implantation of the knee: multicenter experience and minimum 3-year follow-up. Clin J Sport Med 11:223-228

74. Minas T (2001) Autologous chondrocyte implantation for focal chondral defects of the knee. Clin Orthop Relat Res 391:S349S361
75. Minas T, Bryant T (2005) The role of autologous chondrocyte implantation in the patellofemoral joint. Clin Orthop Relat Res 436:30-39

76. Mithöfer K, Minas T, Peterson L, Yeon H, Micheli LJ (2005) Functional outcome of knee articular cartilage repair in adolescent athletes. Am J Sports Med 33:1147-1153

77. Mithöfer K, Peterson L, Mandelbaum BR, Minas T (2005) Articular cartilage repair in soccer players with autologous chondrocyte transplantation: functional outcome and return to competition. Am J Sports Med 33:1639-1646

78. Muellner T, Knopp A, Ludvigsen TC, Engebretsen L (2001) Failed autologous chondrocyte implantation. Complete atraumatic graft delamination after two years. Am J Sports Med 29:516-519

79. Nehrer S, Breinan HA, Ramappa A, Shortkroff S, Young G, Minas T, Sledge CB, Yannas IV, Spector M (1997) Canine chondrocytes seeded in type I and type II collagen implants investigated in vitro. J Biomed Mater Res 38:95-104

80. Nehrer S, Breinan HA, Ramappa A, Young G, Shortkroff S, Louie LK, Sledge CB, Yannas IV, Spector M (1997) Matrix collagen type and pore size influence behaviour of seeded canine chondrocytes. Biomaterials 18:769-776

81. Nehrer S, Breinan HA, Ramappa A, Hsu HP, Minas T, Shortkroff S, Sledge CB, Yannas IV, Spector M (1998) Chondrocyteseeded collagen matrices implanted in a chondral defect in a canine model. Biomaterials 19:2313-2328

82. Nehrer S, Domayer S, Dorotka R, Schatz K, Bindreiter U, Kotz $R$ (2006) Three-year clinical outcome after chondrocyte transplantation using a hyaluronan matrix for cartilage repair. Eur $\mathbf{J}$ Radiol 57:3-8

83. Ochi M, Uchio Y, Kawasaki K, Wakitani S, Iwasa J (2002) Transplantation of cartilage-like tissue made by tissue engineering in the treatment of cartilage defects of the knee. J Bone Joint Surg Br 84:571-578

84. Ossendorf C, Kaps C, Kreuz PC, Burmester GR, Sittinger M, Erggelet C (2007) Treatment of posttraumatic and focal osteoarthritic cartilage defects of the knee with autologous polymerbased three-dimensional chondrocyte grafts: 2-year clinical results. Arthritis Res Ther 9:R41

85. Pavesio A, Abatangelo G, Borrione A, Brocchetta D, Hollander AP, Kon E, Torasso F, Zanasi S, Marcacci M (2003) Hyaluronan-based scaffolds (Hyalograft $C$ ) in the treatment of knee cartilage defects: preliminary clinical findings. Novartis Found Symp 249:203-217

86. Perka C, Sittinger M, Schultz O, Spitzer RS, Schlenzka D, Burmester GR (2000) Tissue engineered cartilage repair using cryopreserved and noncryopreserved chondrocytes. Clin Orthop Relat Res 378:245-254

87. Peterson L, Minas T, Brittberg M, Nilsson A, Sjogren-Jansson E, Lindahl A (2000) Two- to 9-year outcome after autologous chondrocyte transplantation of the knee. Clin Orthop Relat Res 374:212-234

88. Peterson L, Brittberg M, Kiviranta I, Akerlund EL, Lindahl A (2002) Autologous chondrocyte transplantation. Biomechanics and long-term durability. Am J Sports Med 30:2-12

89. Peterson L, Minas T, Brittberg M, Lindahl A (2003) Treatment of osteochondritis dissecans of the knee with autologous chondrocyte implantation: results at two to ten years. J Bone Joint Surg Am 85(Suppl 2):17-24

90. Pontz B, Meigel W, Rauterberg J, Kuhn K (1970) Localization of two species specific antigenic determinants on the peptide chains of calf skin collagen. Eur J Biochem 16:50-54

91. Potter HG, Linklater JM, Allen AA, Hannafin JA, Haas SB (1998) Magnetic resonance imaging of articular cartilage in the knee. An evaluation with use of fast-spin-echo imaging. J Bone Joint Surg Am 80:1276-1284 
92. Rahfoth B, Weisser J, Sternkopf F, Aigner T, von der Mark K, Bräuer R (1998) Transplantation of allograft chondrocytes embedded in agarose gel into cartilage defects of rabbits. Osteoarthr Cartil 6:50-65

93. Recht M, Bobic V, Burstein D, Disler D, Gold G, Gray M, Kramer J, Lang P, McCauley T, Winalski C (2001) Magnetic resonance imaging of articular cartilage. Clin Orthop Relat Res 391:S379-S396

94. Richardson JB, Caterson B, Evans EH, Ashton BA, Roberts S (1999) Repair of human articular cartilage after implantation of autologous chondrocytes. J Bone Joint Surg Br 81:1064-1068

95. Roberts S, McCall IW, Darby AJ, Menage J, Evans EH, Harrison PE, Richardson JB (2003) Autologous chondrocyte implantation for cartilage repair: monitoring its success by magnetic resonance imaging and histology. Arthritis Res Ther 5:R60-R73

96. Robinson D, Halperin H, Nevo Z (1990) Regenerating hyaline cartilage in articular defects of old chickens using implants of embryonal chick chondrocytes embedded in a new natural delivery substance. Calcif Tissue Int 46:246-253

97. Rotter N, Aigner J, Naumann A, Planck H, Hammer C, Burmester G, Sittinger M (1998) Cartilage reconstruction in head and neck surgery: comparison of resorbable polymer scaffolds for tissue engineering of human septal cartilage. J Biomed Mater Res 42:347-356

98. Schuman L, Buma P, Versleyen D, de Man B, van der Kraan PM, van den Berg WB, Homminga GN (1995) Chondrocyte behaviour within different types of collagen gel in vitro. Biomaterials 16:809-814

99. Sechriest VF, Miao Y, Niyibizi C, Westerhausen-Larson A, Matthew H, Evans C, Fu F, Suh J (2000) GAG-augmented polysaccharide hydrogel: a novel biocompatible and biodegradable material to support chondrogenesis. J Biomed Mater Res 49:534-541

100. Sittinger M, Bujia J, Minuth WW, Hammer C, Burmester GR (1994) Engineering of cartilage tissue using bioresorbable polymer carriers in perfusion culture. Biomaterials 15:451-456

101. Sohn DH, Lottman LM, Lum LY, Kim SG, Pedowitz RA, Coutts RD, Sah RL (2002) Effect of gravity on localization of chondrcytes implanted in cartilage defects. Clin Orthop Relat Res 394:254-262

102. Solchaga LA, Dennis JE, Goldberg VM, Caplan AI (1999) Hyaluronic acid-based polymers as cell carriers for tissueengineered repair of bone and cartilage. J Orthop Res 17:205213

103. Solchaga LA, Yoo JU, Lundberg M, Dennis JE, Huibregtse BA, Goldberg VM, Caplan AI (2000) Hyaluronan-based polymers in the treatment of osteochondral defects. J Orthop Res 18:773780

104. Steinwachs M, Kreuz PC (2007) Autologous chondrocyte implantation in chondral defects of the knee with a type I/III collagen membrane: a prospective study with a 3-year followup. Arthroscopy 23:381-387

105. Sun D, Aydelotte MB, Maldonado B, Kuettner KE, Kimura JH (1986) Clonal analysis of the population of chondrocytes from the swarm rat chondrosarcoma in agarose culture. J Orthop Res 4:427-436

106. van Susante JL, Buma P, van Osch GJ, Versleyen D, van der Kraan PM, van der Berg WB, Homminga GN (1995) Culture of chondrocytes in alginate and collagen carrier gels. Acta Orthop Scand 66:549-556
107. van Susante JL, Buma P, Schuman L, Homminga GN, van den Berg WB, Veth RP (1999) Resurfacing potential of heterologous chondrocytes suspended in fibrin glue in large full-thickness defects of femoral articular cartilage: an experimental study in the goat. Biomaterials 20:1167-1175

108. Takahashi T, Tins B, McCall IW, Richardson JB, Takagi K, Ashton K (2006) MR appearance of autologous chondrocyte implantation in the knee: correlation with the knee features and clinical outcome. Skeletal Radiol 35:16-26

109. Tins BJ, McCall IW, Takahashi T, Cassar-Pullicino V, Roberts S, Ashton B, Richardson J (2005) Autologous chondrocyte implantation in knee joint: MR imaging and histologic features at 1-year follow-up. Radiology 234:501-508

110. Tognana E, Padera RF, Chen F, Vunjak-Novakovic G, Freed LE (2005) Development and remodeling of engineered cartilageexplant composites in vitro and in vivo. Osteoarthr Cartil 13:896-905

111. Trattnig S, Ba-Ssalamah A, Pinker K, Plank C, Vecsei V, Marlovits S (2005) Matrix-based autologous chondrocyte implantation for cartilage repair: noninvasive monitoring by high-resolution magnetic resonance imaging. Magn Reson Imaging 23:779-787

112. Trattnig S, Mamisch TC, Welsch GH, Glaser C, Szomolanyi P, Gebetsroither S, Stastny O, Horger W, Millington S, Marlovits S (2007) Quantitative T2 mapping of matrix-associated autologous chondrocyte transplantation at 3 Tesla: an in vivo crosssectional study. Invest Radiol 42:442-448

113. Trattnig S, Marlovits S, Gebetsroither S, Szomolanyi P, Welsch GH, Salomonowitz E, Watanabe A, Deimling M, Mamisch TC (2007) Three-dimensional delayed gadolinium-enhanced MRI of cartilage (dGEMRIC) for in vivo evaluation of reparative cartilage after matrix-associated autologous chondrocyte transplantation at 3.0T: preliminary results. J Magn Reson Imaging 26:974-982

114. Uchio Y, Ochi M, Matsusaki M, Kurioka H, Katsube K (2000) Human chondrocyte proliferation and matrix synthesis cultured in atelocollagen gel. J Biomed Mater Res 50:138-143

115. Visna P, Pasa L, Cizmár I, Hart R, Hoch J (2004) Treatment of deep cartilage defects of the knee using autologous chondrograft transplantation and by abrasive techniques-a randomized controlled study. Acta Chir Belg 104:709-714

116. Wakitani S, Kimura T, Hirooka A, Ochi T, Yoneda M, Yasui N, Owaki H, Ono K (1989) Repair of rabbit articular surfaces with allograft chondrocytes embedded in collagen gel. J Bone Joint Surg Br 71:74-80

117. Wakitani S, Goto T, Pineda SJ, Young RG, Mansour JM, Caplan AI, Goldberg VM (1994) Mesenchymal cell-based repair of large, full-thickness defects of articular cartilage. J Bone Joint Surg Am 76:579-592

118. Willers C, Chen J, Wood D, Xu J, Zheng MH (2005) Autologous chondrocyte implantation with collagen bioscaffold for the treatment of osteochondral defects in rabbits. Tissue Eng 11:1065-1076

119. Wood JJ, Malek MA, Frassica FJ, Polder JA, Mohan AK, Bloom ET, Braun MM, Coté TR (2006) Autologous cultured chondrocytes: adverse events reported to the United States Food and Drug Administration. J Bone Joint Surg Am 88:503-507

120. Zheng MH, Willers C, Kirilak L, Yates P, Xu J, Wood D, Shimmin A (2007) Matrix-induced autologous chondrocyte implantation (MACI): biological and histological assessment. Tissue Eng 13:737-746 